\title{
Characteristics and composition of tomato seed oil
}

\author{
By Evangelos S. Lazos*, John Tsaknis and Stavros Lalas \\ Department of Food Technology. Faculty of Food Technology \& Nutrition. \\ Technological Educational Institution of Athens. Agiou Spiridonos Str., Egaleo, 12210 Athens, \\ Greece. E-mail: elazos@athena.teiath.gr
}

\section{RESUMEN}

\section{Características y composición del aceite de semilla de tomate}

Se separaron semillas de tomate de la pulpa seca y posteriormente se trituraron y extrajeron con éter de petróleo en caliente. El aceite extraído se desgomó, neutralizó y decoloró, y luego se determinaron las características físicas y químicas de los aceites crudos y purificados. La purificación produjo una disminución en la acidez, color, insaponificables, $E_{1 \mathrm{~m}}^{1 \%} 232$ y estabilidad oxidativa y un aumento en el punto de humo y $E_{1 \mathrm{~cm}}^{1 \%} 270$. Las propiedades físico-químicas no se afectaron por la purificación. Se encontró que el aceite de semilla de tomate contenía altos niveles de linoleico (54\%), seguido por oleico (22\%), mientras que los ácidos grasos saturados mayoritarios fueron el palmítico (14\%) y el esteárico $(6 \%)$. La purificación produjo también un aumento en el C 18:2 trans, mientras que el perfil de ácidos grasos del aceite permaneció inalterado. Se detectaron $\alpha$ - y $\delta$ - tocoferoles a niveles de 202 y $1059 \mathrm{mg} / \mathrm{kg}$; la purificación redujo el contenido en tocoferol a 161 y $898 \mathrm{mg} / \mathrm{kg}$, respectivamente. El $\beta$-sitosterol fue el componente predominante de la fracción esterólica del aceite de semilla de tomate. Se detectó un alto porcentaje de colesterol $(16 \%)$. Otros esteroles encontrados en porcentajes más elevados del $1.5 \%$ fueron el campesterol, estigmasterol y $\Delta^{5}$-avenasterol. Además, se encontraron como componentes minoritarios 24-metilenecolesterol, brasicasterol, $\Delta^{7}$-campesterol, clerosterol, $\Delta^{7},{ }^{24}$. estigmastadienol, $\Delta^{7}$-estigmastanol, $\Delta^{7}$-avenasterol y eritrodiol. El perfil de esteroles no se afectó por la purificación.

PALABRAS-CLAVE: Aceite de semilla de tomate - Acido graso - Estabilidad - Esterol - Purificación - Tocoferol.

\section{SUMMARY}

\section{Characteristics and composition of tomato seed oil}

Tomato seeds were separated from dried pomace, and seeds were ground and extracted with hot petroleum ether. The extracted oil was degummed, neutralised and bleached, and then the physical and chemical characteristics of crude and purified oils were determined. Purification led to a decrease in acidity, colour, unsaponifiables, $E_{1 \mathrm{~cm}}^{1 \%} 232$ and oxidative stability, and to an increase in smoke point and $E_{1 \mathrm{~cm}}^{1 \%} 270$. The fundamental physicochemical properties of the oil were not affected by purification. Tomato seed oil was found to contain high levels of linoleic (54\%), followed by oleic $(22 \%)$, while the dominant saturated acids were palmitic $(14 \%)$ and stearic $(6 \%)$. Purification led to an increase in C18:2trans, while the fatty acid profile of the oil remained unchanged. $\alpha$ - and $\delta$-tocopherols were detected at levels of 202 and 1059 $\mathrm{mg} / \mathrm{kg}$; purification reduced tocopherol content to 161 and 898 $\mathrm{mg} / \mathrm{kg}$, respectively. $\beta$-sitosterol was found as the most predominant component of the sterolic fraction from tomato seed oil. A large percentage $(16 \%)$ of cholesterol was detected. Other sterols found in percentages higher than $1.5 \%$ were campesterol, stigmasterol and $\Delta^{5}$-avenasterol. In addition, trace to minor amounts of 24methylenecholesterol, brassicasterol, $\Delta^{7}$-campesterol, clerosterol, $\Delta^{7},{ }^{24}$-stigmastadienol, $\Delta^{7}$-stigmastanol, $\Delta^{7}$-avenasterol and erythrodiol were found. Sterol profile was not affected by purification.

KEY-WORDS: Fatty acid - Purification - Stability - Sterol - Tocopherol - Tomato seed oil.

\section{INTRODUCTION}

Tomato pomace, a waste product from tomato processing plants, consists of skins, pulp and seeds. The major component of tomato pomace is the seeds, which are considered to be a good source of an edible oil $(1,2,3,4,5)$. Tomato is one of the most widely cultivated vegetable crops in Greece. According to data received from the Ministry of Agriculture of Greece, the amounts of tomatoes produced for industrial processing were for the year $19941,105,984$ metric tons, for $19951,020,740$ tons and for $19961,268,930$ tons, while additional amounts of $565,712,513,217$ and 600,040 tons, respectively for the three years, have been produced for raw consumption (salad and cooking). Thus, the amount of seeds resulting annually is quite enough to produce 1,300 to 2,000 tons of edible oil. The oil has a high unsaturated acid content, with over $50 \%$ linoleic acid $(3,4)$ and could be used in cooking. Besides, tomato seed cake was found to contain $23-39 \%$ protein with good functional and nutritional properties $(6,7,8)$. In addition, the seeds have been reported to posses antioxidant properties $(9,10)$.

Though data on tomato seed oil composition are already available in literature, more detailed information is needed, as in many cases they remain controversial. The objective of the present work was to contribute to extent the knowledge of chemical composition of tomato seed oil as well as to determine the effect of purification on it. Such data will be useful for studying the behavior of the oil during heating and processing. 


\section{MATERIALS AND METHODS}

\section{Sample preparation and oil purification}

Samples of tomato pomace were obtained from tomato processing plants of Kopais region, Greece. Quantities of $20 \mathrm{~kg}$ of pomace were collected twice per week and for a total period of one month, from two different plants. After receiving, the samples were dried in an air-dryer (Apex Construction Ltd., England) at $60^{\circ} \mathrm{C}$, ground in a blender and the seeds were separated using a sieve system of 2.0 and 1.6 $\mathrm{mm}$. The separated seeds of all samples were combined and then ground to a powder by a Brabender mill to pass through a $0.70 \mathrm{~mm}$ sieve. Batches of ground seeds were extracted for $15 \mathrm{hr}$ with petroleum ether (b.p. $40-60^{\circ} \mathrm{C}$ ) in $2 \mathrm{~L}$ Soxhlet extractors. The solvent was evaporated under reduced pressure, and the oils from different batches were combined and kept in sealed bottles under refrigeration $\left(0-4^{\circ} \mathrm{C}\right)$ for further processing and analysis.

Tomato seed oil was degummed using the following procedure developed in our laboratory. Fifty grams of oil were put in $100 \mathrm{~mL}$ capacity pyrex test tubes and then were immersed in a water-bath adjusted at $90^{\circ} \mathrm{C}$. Afterwards, a $3 \%(\mathrm{w} / \mathrm{w})$ water at $80^{\circ} \mathrm{C}$ and $0.3 \%(\mathrm{w} / \mathrm{w})$ phosphoric acid were added under continuous stirring. The mixture was stirred for $10 \mathrm{~min}$, cooled, centrifuged for $5 \mathrm{~min}$ at $3000 \mathrm{rpm}$, and decanted to obtain degummed oil.

Batches of $500 \mathrm{~g}$ of oil were put into $1 \mathrm{~L}$ beakers, heated at $80^{\circ} \mathrm{C}$, and then $4.7 \mathrm{~mL}$ of $4.125 \mathrm{M} \mathrm{NaOH}$ were added under continuous stirring. Stirring was continued for $40 \mathrm{~min}$ to coagulate the soap, and then left to stand for soap separation. Most of the neutralized oil was obtained by decanting, and the remaining soap-stock was centrifuged at $3000 \mathrm{rpm}$ for further oil separation. Afterwards, the oil was transferred into a separatory funnel and was washed with $15 \%(\mathrm{w} / \mathrm{w})$ distilled water $\left(80^{\circ} \mathrm{C}\right)$ by shaking vigorously the separatory funnel, and allowed to stand for $15 \mathrm{~min}$. The lower aqueous layer was separated and discarded.

The purified oil was heated at $105^{\circ} \mathrm{C}$ for moisture removal, and afterwards, was bleached by adding $3 \%$ Tonsil Optimum earth technical powder, plus $2 \%$ activated carbon. The mixture was stirred for $15 \mathrm{~min}$ and then filtered under vacuum using a Whatman No 1 filter paper. The color of the oil as measured by a Lovibond tintometer was changed from the initial 22 red and 10 yellow units to 10 red and 2 yellow units.

\section{Analytical procedures}

Free fatty acids (FFA), peroxide value (PV), and ultra-violet absorption at 232 and $270 \mathrm{~nm}$ were determined using the IUPAC methods (11). lodine value (IV) was determined using the Wijs method as described in Pearson's (12). Refractive index of the oil was measured at $40^{\circ} \mathrm{C}$ with an Abbe refractometer with temperature adjustment; color was measured with a Lovibond tintometer; viscosity was measured using a Brookfield LVT rotational viscometer equipped with a No 2 spindle rotated at $60 \mathrm{rpm}$ at $21^{\circ} \mathrm{C}$; and smoke point with a method adapted from that described by BS 648:Section 1.8 (13). Oil stability was evaluated by the Rancimat method using the Rancimat 679 until the oil batch reached the temperature of $120^{\circ} \mathrm{C}$ and with an air flow rate set at $20 \mathrm{~L} / \mathrm{hr}$. Extra virgin olive oil and sunflower oil (ELAIS SA, Athens, Greece) without added antioxidants were examined concurrently for comparison reasons.

Fatty acids were characterized by gas-liquid chromatography (GLC). The fatty acid methyl esters (FAME) were prepared according to the following method optimized in our laboratory and based on the well known methanolic $\mathrm{NaOH}-\mathrm{BF}_{3}-\mathrm{MeOH}$ method $(14,15)$. About $25 \mathrm{mg}$ of oil was accurately weighed into a screw cap tube and $1.5 \mathrm{~mL} 0.5 \mathrm{M}$ methanolic sodium hydroxide was added, mixed and heated at $100^{\circ} \mathrm{C}$ for 7 minutes. After cooling $2 \mathrm{~mL}$ of boron trifluoride was added and heated at $100^{\circ} \mathrm{C}$ for 5 minutes. The tube was cooled to $30-40^{\circ} \mathrm{C}$ and $1 \mathrm{~mL}$ iso-octane was added, capped and shaken using a whirli mix for 30 seconds. $5 \mathrm{~mL}$ of saturated sodium chloride solution was immediately added and the tube was shaken again. The tube contents were allowed to separate and the top (iso-octane containing FAME) layer was removed and the lower layer was re-extracted with an additional $1 \mathrm{~mL}$ iso-octane. The two iso-octane extracts were combined, dried over anhydrous sodium sulfate if necessary, and concentrated to approximately $1 \mathrm{~mL}$ using a nitrogen stream. Internal standard solution for FAME determination was prepared by dissolving $100 \mathrm{mg}( \pm 0.1 \mathrm{mg})$ pentadecanoic acid $(\mathrm{C} 15: 0)$ in 50 $\mathrm{mL}$ iso-octane (16). One $\mathrm{mL}$ and/or $500 \mu \mathrm{L}$ of the internal standard solution were added into oil and treated as previously described.

The analysis of FAME were performed with a Carlo Erba 5600 gas-liquid chromatograph equipped with a 50 $\mathrm{m}, 0.22 \mathrm{~mm}$ ID, $0.25 \mu \mathrm{m}$ thickness, BPx70 capillary column. Operating conditions were as follows: Helium flow rate $25.6 \mathrm{~mL} / \mathrm{min}$; injector and detector (FID with hydrogen flow $40 \mathrm{~mL} / \mathrm{min}$ and air flow $450 \mathrm{~mL} / \mathrm{min}$ ) temperatures were $235^{\circ} \mathrm{C}$. The temperature programme was 160 $210^{\circ} \mathrm{C}$ at a rate of $1.5^{\circ} \mathrm{C} / \mathrm{min}$, initial time at $160^{\circ} \mathrm{C}$ was $0.0 \mathrm{~min}$ and final time at $210^{\circ} \mathrm{C}$ was $5.0 \mathrm{~min}$. Methyl esters were identified and quantified by comparing the retention time and peak area of the unknowns with those of FAME standards (British Greyhound, Chromatography and Allied Chemicals).

Tocopherols were determined by high performance liquid chromatography (HPLC) using a modification 
of Carpenter's method (17). One gram of oil was accurately weighed into a 3 dram sample vial wrapped in foil paper to prevent oxidation. The oil was dissolved in 5 $\mathrm{mL}$ n-hexane, HPLC grade, before injection. A $20 \mu \mathrm{L}$ sample was injected into a Waters 600E HPLC fitted with a $\mu$-Polarsil, $125 \AA, 10 \mu \mathrm{m}, 3.9 \times 300 \mathrm{~mm}$ HPLC column with the following characteristics: irregularly-shaped silica. Detection was made with a Waters 486 Tunable Absorbance Detector set at $295 \mathrm{~nm}$. Iso-propanol:nhexane: absolute ethanol (2:97.5:0.5) at $1 \mathrm{~mL} / \mathrm{min}$ was used as mobile phase. Waters Baseline 815 programme running on a computer was used as integrator for the determination of the standard calibration curves and for the calculation of the amounts of tocopherols in the oil samples. Tocopherols obtained from Merck (DL-a-tocopherol) and Sigma $((+)-\delta$-tocopherol), were used as standards.

Unsaponifiable matter and sterols were determined using the standard method of the Official Journal of the European Communities (18). Unsaponifiables were prepared by saponification with ethanolic $\mathrm{KOH}$ $2 \mathrm{M}$, washing and ether extraction using $500 \mu \mathrm{L} / 5 \mathrm{~g}$ solvent of a $0.2 \% \alpha$-cholestanol solution as an internal standard. Sterolic fraction was separated by TLC using silica gel plates, developed with a 65:35 (v/v) hexane:ethyl ether mixture, spraying with 2,7-dichlorofluorescein, scraping and extracting with chloroform and ethyl ether. Sterols were converted to trimethylsilyl (TMS) ethers using a silylation reagent consisting of a 9:3:1 $(\mathrm{v} / \mathrm{v} / \mathrm{v})$ mixture of pyridine:hexamethyldisilazane: trimethylchlorosilane in the ratio of $50 \mu \mathrm{L}$ for every milligram of sterols. The measurement was done on a Carlo Erba 5600 Gas Chromatograph using a 25m x $0.35 \mathrm{~mm} \times 0.25 \mu \mathrm{m}$ WCOT Fused Silica 7452 CP-Sil-8CB capillary column. The pressure of the carrier gas $\left(\mathrm{H}_{2}\right)$ was $110 \mathrm{kPa}$. Injector and FID temperatures were $280^{\circ} \mathrm{C}$ and $300^{\circ} \mathrm{C}$ respectively. The temperature programme was isothermal $260^{\circ} \mathrm{C}$ for $40 \mathrm{~min}$ at least. Sterols obtained from Laroden $A B$ (Sweden), were used as standards.

\section{RESULTS AND DISCUSSION}

The oil content of tomato seeds was found to be $21.8 \%$, and fell in the range previously reported for seeds received from tomato processing plants $(2,4,5,19)$. The seed oil was a red-yellowish liquid at ambient temperature and had a mild tomato fruit-like odor.

The physical and chemical characteristics of crude and purified tomato seed oil are shown in Table I. It is apparent that purification did not alter the fundamental physicochemical characteristics of the oil. As expected, the basic changes happened are referred to a decrease in acidity, color and unsaponifiables, as a result of degumming, neutralisation and bleaching. An increase in smoke point was observed due to free fatty acid reduction, as they are much more volatile than glycerides, and hence, smoke point depends on the free fatty acid content (20). The obtained values for density and refractive index are in line with those reported in literature $(2,4)$. Viscosity values were similar to those for olive and cottonseed oils and much higher than those for corn, peanut, soybean, and safflower oils $(20,21)$. The peroxide value of tomato seed oil was lower than $20 \mathrm{meq} / \mathrm{kg}$ and fell in the range adopted as satisfactory. There was no change in peroxide value during purification and bleaching. This may be due to tocopherols and hence, purified tomato seed oil should expected to show an overall lower stability compared to crude oil. A $4.85 \%$ reduction in induction time, as measured by Rancimat, was observed (Table I), which could be attributed to oil purification. Tomato seed oil has values for specific extinction in UV at 232 and $270 \mathrm{~nm}$ similar to other vegetable oils such as olive and sunflower oils (22). Generally, R-value is higher if secondary oxidative changes are lower, i.e., the value for $E_{1 \% m}^{1 \%} 270$, though the same peroxide values show different values for specific extinction. Laboratory purification led to a decrease in $E_{1 \mathrm{~cm}}^{1 \%} 232$ and to an increase in $E_{1 \mathrm{~cm}}^{1 \%}$ 270 , resulting in a decrease in R-value (Table I). Similar findings have been reported by Vogel (23) for pumpkin seed oil, who furthermore reported that bleaching and deodorisation exert the main action, while degumming and neutralization had no actual effect on specific extinction.

The saponification value was in the reported range $(2,4)$. The oil had a high iodine value, thus reflecting a high degree of unsaturation.

Table II shows the fatty acid composition of tomato seed oil. Total unsaturated fatty acids were $80 \%$, while the major fatty acid was linoleic (C18:2) in a concentration of $54 \%$, followed by oleic (C18:1), $22 \%$. Generally, the level of linoleic acid falls in the range of $50-60 \%$, while Swem (20) reports concentrations of oleic acid higher (46\%) than those of linoleic (35\%). Palmitic acid (C16:0) was found to be the dominant saturated fatty acid and was in line with values reported $(1,4,5$, $20,24,25)$. Higher palmitic acid concentrations, in the range of $20.28-24.81 \%$, have been reported by El-Tamimi et al., (3). The same authors have also reported lower concentrations for stearic acid (C18:0), $2.36-2.96 \%$, and relatively high concentrations of arachidic acid (C20:0), 1.93-2.20\%. The concentrations of $\mathrm{C} 20: 0$ found in the present study were in agreement with those reported by Tsatsaronis and Boskou (26), and Lazos and Kalathenos (4). Small to trace amounts of C14:0, C16:1, C17:0, C18:2trans, C20:0, C20:1, $\mathrm{C} 22: 0$ and $\mathrm{C} 24: 0$ were also found in tomato seed oil. Tsatsaronis and Boskou (26) have reported that oddand even-chain length saturated acids from C12:0-C28:0, except C21:0, were present in the oil. Based on results obtained the fatty acid composition of tomato seed oil showed that it falls in the linoleic-oleic acid oils category. Therefore the oil could be useful for edible purposes and for some industrial applications like hydrogenation, shortening production and others. 
Table I

Physical and chemical characteristics of tomato seed oil

\begin{tabular}{|c|c|c|}
\hline \multirow{2}{*}{ Characteristic } & \multicolumn{2}{|c|}{ Value $^{1}$} \\
\hline & Crude & Purified \\
\hline Density, $25^{\circ} \mathrm{C}$ & $0.9160 \pm 0.00024$ & $0.9156 \pm 0.00019$ \\
\hline Refractive index, $40^{\circ} \mathrm{C}$ & $1.4603 \pm 0.00022$ & $1.4610 \pm 0.00016$ \\
\hline Viscosity $\left(21^{\circ} \mathrm{C}\right), \mathrm{mPa} . \mathrm{s}$ & $75 \pm 0.4$ & $74 \pm 0.3$ \\
\hline Smoke point, ${ }^{\circ} \mathrm{C}$ & $176 \pm 63.0$ & $208 \pm 5.4$ \\
\hline \multicolumn{3}{|l|}{ Colour } \\
\hline red units & $22 \pm 0.5$ & $10 \pm 0.1$ \\
\hline yellow units & $10 \pm 0.1$ & $2 \pm 0.0$ \\
\hline Saponification number & $184 \pm 6.9$ & $186 \pm 2.5$ \\
\hline lodine value & $105 \pm 0.7$ & $104 \pm 0.9$ \\
\hline Unsaponifiable matter, \% & $1.4 \pm 0.02$ & $0.9 \pm 0.01$ \\
\hline Acidity, $\%$ as oleic & $1.01 \pm 0.0008$ & $0.05 \pm 0.0001$ \\
\hline Peroxide value, meq $/ \mathrm{kg}$ & $9.3 \pm 0.055$ & $9.1 \pm 0.054$ \\
\hline \multicolumn{3}{|l|}{ Induction time } \\
\hline tomato & $5.15 \pm 0.012$ & $4.9 \pm 0.016$ \\
\hline olive & $7.22 \pm 0.027$ & \\
\hline sunflower & $3.40 \pm 0.014$ & \\
\hline$E \%_{c m}^{\%} 232$ & $2.40 \pm 0.0001$ & $2.23 \pm 0.0001$ \\
\hline$E_{1 \mathrm{~cm}}^{1 \%} 270$ & $0.63 \pm 0.00004$ & $0.72 \pm 0.00003$ \\
\hline $\mathrm{R}=E_{1 \mathrm{~cm}}^{1 \%} 232 / E_{1 \mathrm{~cm}}^{1 \%} 270$ & $3.81 \pm 0.0002$ & $3.11 \pm 0.00009$ \\
\hline
\end{tabular}

1 Average of three samples with three to five replications, \pm standard deviation.

Table II

Fatty acid composition of tomato seed oil ${ }^{1}$

\begin{tabular}{lcc}
\hline \multirow{2}{*}{ Fatty acid } & \multicolumn{2}{c}{$\%$} \\
\cline { 2 - 3 } & Crude & Purified \\
\hline C14:0 & $0.2 \pm 0.0001$ & $0.1 \pm 0.0000$ \\
C16:0 & $14.0 \pm 0.12$ & $13.6 \pm 0.10$ \\
C16:1 cis $\omega 9$ & $0.4 \pm 0.0004$ & $0.6 \pm 0.0001$ \\
C16:1 cis $\omega 7$ & $0.1 \pm 0.0000$ & $N^{2}$ \\
C17:0 & $0.3 \pm 0.003$ & $0.1 \pm 0.0002$ \\
C18:0 & $6.0 \pm 0.01$ & $6.0 \pm 0.05$ \\
C18:1 $\omega 9$ & $22.0 \pm 0.21$ & $22.0 \pm 0.12$ \\
C18:1 $\omega 7$ & $0.6 \pm 0.001$ & $0.1 \pm 0.0001$ \\
C18:2 & $53.6 \pm 0.28$ & $54.0 \pm 0.65$ \\
C18:2trans & $0.1 \pm 0.0000$ & $0.8 \pm 0.0002$ \\
C18:3 & $2.0 \pm 0.003$ & $2.1 \pm 0.002$ \\
C20:0 & $0.3 \pm 0.0001$ & $0.2 \pm 0.0001$ \\
C20:1 & $0.1 \pm 0.0000$ & $0.2 \pm 0.0000$ \\
C22:0 & Trace & - \\
C24:0 & $0.1 \pm 0.0000$ & $0.1 \pm 0.0000$ \\
\hline
\end{tabular}

${ }_{3}$ Average of three samples, \pm standard deviation; ${ }^{2} \mathrm{ND}=$ not detected; ${ }^{3}$ trace $<0.1 \%$
Furthermore, it should be pointed out that the fatty acid pattern has not changed during purification and bleaching of the oil. However, the concentration of C18:2trans was increased from $0.1 \%$ in the crude oil to $0.8 \%$ in purified oil (Table II). This is due to high temperature clay bleaching, which causes cis-trans isomerization (20).

A high tocopherol content was found in tomato seed oil, consisting of $\alpha$-and $\delta$-tocopherol, at concentrations of 202 and $1059 \mathrm{mg} / \mathrm{kg}$, respectively. Dabrowska (1) and Nadirov et al. (27) reported total tocopherol contents from 418 to $767 \mathrm{mg} / \mathrm{kg}$, which can influence the stability of the oil during storage. Purification and bleaching led to a reduction in tocopherol contents to values of 161 and $898 \mathrm{mg} / \mathrm{kg}$, for $\alpha$ - and $\delta$-tocopherol respectively, corresponding to a 80 and $85 \%$ retention, respectively. It should be noted that the variation in the amount of tocopherols lost during refining depends on the severity of the process with respect to temperature and time, and to crude oil condition. McLaughlin and Weihrauch (28) reported that deodorization causes the greatest loss of tocopherols, while little or no tocopherol is destroyed during hydrogenation. More recently, Jung et al. (29) showed that the most substantial loss during refining of soybean oil occurred at the deodorization stage, while degumming, neutralization and bleaching led to an average retention of $88 \%$. This value is very close to the value found in this work.

Tomato seed oil showed lower induction time than olive oil and higher than that of sunflower oil (Table I). Although tomato seed oil shows a similar fatty acid profile with sunflower oil (20), the latter showed lower induction time, which among others could be attributed to lower tocopherol content in sunflower, $636 \mathrm{mg} / \mathrm{kg}$, of which $\alpha$-tocopherol accounts for $96 \%$, followed by $\beta$-tocopherol, $2.5 \%$, and $\gamma$-tocopherol, $1.5 \%$ (30). Nevertheless, the higher oxidative stability of tomato seed oil over sunflower oil should be attributed to other constituents of non glyceride fraction of the oil, which posses antioxidant properties.

The results of qualitative and quantitative sterol determinations in the sterolic fraction of tomato seed oil unsaponifiables are summarised in Table III. Total sterol content in crude oil varied between 325 and $533 \mathrm{mg} / 100 \mathrm{~g}$ with an average value of $455 \pm 89$ $\mathrm{mg} / 100 \mathrm{~g}$, while in purified oil between 225 and 368 $\mathrm{mg} / 100 \mathrm{~g}$ with an average of $315 \pm 60 \mathrm{mg} / 100 \mathrm{~g}$. The sterol fraction of the tomato seed oil consisted mainly of campesterol, stigmasterol, $\beta$-sitosterol and $\Delta^{5}$-avenasterol, among of which $\beta$-sitosterol was the most predominant, accompanied with trace or minute amounts of 24-methylenecholesterol, brassicasterol, $\Delta^{7}$-campesterol, clerosterol, $\Delta^{7},{ }^{24}$-stigmastadienol, $\Delta^{7}$-stigmastanol, $\Delta^{7}$-avenasterol and erythrodiol. In addition, cholesterol at a level of $16 \%$ was found, which was the second quantitatively important sterol of tomato seed oil after $\beta$-sitosterol. Yamamoto and 
Mackinney (31) mentioned only the existence of stigmasterol, $\beta$-sitosterol and possibly campesterol in tomato fruit and seeds. The results obtained in this study were in good agreement with those previously reported $(4,32,33,34)$, although higher concentrations for cholesterol approaching $27 \%$ have been reported. An unusually high concentration (up to $41 \%$ ) of cholesterol has been reported by Kiosseoglou and Boskou (35). Ismail et al. (36) have reported a total cholesterol concentration of $30 \mathrm{mg} / 100 \mathrm{~g}$ for the edible portion of tomatoes. The high cholesterol content in tomato seed oil gives rise to problems in analytical interpretation when controlling the purity of vegetable as well as animal fats. Moreover, the results of the present study confirmed the wide distribution of 24-methylenecholesterol in vegetable oils, which initially was believed to be widely distributed in marine organisms $(37,38)$.

Table III

\section{Composition of sterol fraction of tomato seed oil}

\begin{tabular}{lccc}
\hline \multirow{1}{*}{ Sterol } & RRT $^{2}$ & \multicolumn{2}{c}{$\%$} \\
\cline { 3 - 4 } & & Crude & Purified \\
\hline Cholesterol & 0.64 & $15 \pm 0.2$ & $16 \pm 0.2$ \\
Brassicasterol & 0.71 & $1.5 \pm 0.04$ & $1.1 \pm 0.02$ \\
24-Methylenecholesterol & 0.80 & $1.2 \pm 0.02$ & $0.9 \pm 0.004$ \\
Campesterol & 0.83 & $6.7 \pm 0.14$ & $6.1 \pm 0.06$ \\
Stigmasterol & 0.89 & $14.4 \pm 0.24$ & $14.6 \pm 0.17$ \\
$\Delta^{7}$-Campesterol & 0.92 & $0.3 \pm 0.0003$ & Trace \\
Clerosterol & 0.96 & Trace & ND \\
$\beta$-Sitosterol & 1.00 & $52 \pm 2.22$ & $53 \pm 1.17$ \\
$\Delta^{5}$-Avenasterol & 1.04 & $6.7 \pm 0.022$ & $7 \pm 0.029$ \\
$\Delta^{7},{ }^{24}$-Stigmastadienol & 1.09 & $0.5 \pm 0.0005$ & $0.3 \pm 0.0003$ \\
$\Delta^{7}$-Stigmastenol & 1.11 & $0.4 \pm 0.0003$ & $0.2 \pm 0.0001$ \\
$\Delta^{7}$-Avenasterol & 1.17 & $0.1 \pm 0.0001$ & Trace \\
Erythrodiol & 1.47 & $0.1 \pm 0.0000$ & $\mathrm{ND}$ \\
\hline
\end{tabular}

a Relative retention time for $\beta$-sitosterol (retention time $20.7 \mathrm{~min}$ ) taken as 1.00 1 Average of three samples, \pm standard deviation; ${ }^{2} \mathrm{ND}=$ not detected;

3 trace $<0.1 \%$.

The sterol fraction from tomato seed oil consists mainly of $\Delta^{5}$-sterols with small proportions of $\Delta^{7}$-sterols as in most vegetable oils (38). Oil purification and bleaching did not change the sterol pattern of the oil due to the fact that they are relatively inert. It is known that alkali refining of oils removes a portion of the sterols (20). As a result sterols present in trace or minor amounts in crude oil were not detected in purified oil (Table III).

\section{REFERENCES}

1. Dabrowska, M. (1970).- «Utilization of tomato seeds for oil production".-Prace Instytutow i Laboratoriow Badawczych Przemyslu Spozywczego 20 (4) 511-522.

2. Morad, M.M., El-Tamimi, A.H., Rady, A.H., and Ibrahim, S.S. (1980).- - Tomato seed oil. II. Evaluation of the Egyptian tomato seed oil and the residual meal».-Fette Seifen Anstrichmittel 82 (3) 122-124.

3. El-Tamimi, A.H., Morad, M.M., Raof, M.S., and Rady, A.H. (1979).- - Tomato seed oil. I. Fatty acid composition, stability and hydrogenation of the oil».-Fette Seifen Anstrichmittel, 81 (7) 281-284.

4. Lazos, E.S. and Kalathenos, P. (1988). - "Composition of tomato processing wastes".- Int. J. Food Sci. Technol. 23 649-652.

5. Takasova, J., Drdak, M., and Minarovicova, I. (1995)."Characteristics of lipids in tomato seeds".-Die Nahrung 39 (3) 244-245.

6. Kramer, A. and Kwee, W.H. (1977a).—«Functional and nutritional properties of tomato protein concentrations".J. Food Sci. 42 207-211.

7. Kramer, A. and Kwee, W.H. (1977b)._- «Utilization of tomato processing wastes". J. Food Sci. 42 212-215.

8. Latlief, J.S. and Knorr, D. (1983).- «Tomato seed protein concentrates: effects of methods of recovery upon yield and compositional characteristics".- J. Food Sci. 48 1583-1586.

9. Szanto-Nemeth, E. (1980).— «Inhibition of rancidity of fats by paprika and tomato seeds".-Acta Alimentaria 9 173-187.

10. Guleria, S.P.S., Vasudevan, P., Madhok, K.L., and Patwardhan, S.V. (1983). - "Use of tomato seed powder as an antioxidant in butter and ghee".-J. Food Sci. Technol. India 20 79-80.

11. IUPAC (1987). - «Standard Methods for the Analysis of Oils, Fats and Derivatives".-C. Paquat (ed.), 7th ed. Blackwell Scientific Publications.

12. Egan, H., Kirk R.S., and Sawyer, R. (eds.). (1981).— «Pearson's Chemical Analysis of Foods", 8th ed., pp. 520-547.-Churchill Livingston, Edinburgh.

13. British Standards Methods of Analysis. Fats and Fatty Oils, Part 1. Physical Methods, Section 1.8. Determination of smoke point (1976).

14. Metcalfe, L.D., Schmitz, A.A., and Pelka, J.R. (1966). - «Preparation of fatty acid esters from lipids for gas chromatographic analysis".-Anal. Chem. 38 (3) $514-515$.

15. Morrison, L.D. and Smith, L.M. (1964)._ «Preparation of fatty acid methyl esters and dimethyl acetals from lipids with boron trifluoride-methanol».-J. Lipid Res 5 600-608.

16. Official Journal of the European Communities. (1991a)._- «Fatty acid methyl ester analysis by gas chromatography".-L248/36-47, 5/9/91.

17. Carpenter, A.P.Jr. (1979). - «Determination of tocopherols in vegetable oils".-J. Am. Oil Chem. Soc. 56 668-671.

18. Official Journal of the European Communities (1991b).—-Determination of the composition and content of sterols by capillary-column gas chromatography".L248/15-22, 5/9/91.

19. Gad, A.M., El-Khalafy, H.M., Hassan, M.M., and Shoeb, Z.E. (1968). - «Chemical investigations on Egyptian vegetable fats and oils. XIII. The chemical 
constitution of some Rosaceae, Solanaceae and Oleaceae seed oils".-Grasas y Aceites, 19 (4) 139-145.

20. Swern, D. (1979).- «Bailey's Industrial Oil and Fat Products", Vols. 1\& 2. John Wiley \& Sons, New York.

21. Lewis, M.J. (1987)._ «Physical Properties of Foods and Food Processing Systems". Ellis Horwood, London.

22. Markovic, V.V. and Bastic, L.V. (1976)."Characteristics of pumpkin seed oil».-J. Am. Oil Chem. Soc. 53 42-44.

23. Vogel, P. (1978).- «Untersuchungen uber Kurbiskernol».Fette Seifen Anstrchmittel 80 (8) 315-317.

24. Carol, I. (1968).- «Composition of tomato seed oil».-Ind. Aliment. 18489.

25. Salim, M., Muhammad, D., Ahmad, M., Raie, M.Y. Khan, S.A., and Bhatty, M.K. (1981).— «The fatty acids of indigenous resources for possible industrial applications. VI. Investigations of the species of Solanaceae family".-Pakistan J. Sci. Ind. Res. 24 (1) 21-23.

26. Tsatsaronis, G.C. and Boskou, D. G. (1972).- «Fatty acid composition of tomato seed oil».-JAOAC 53 645-647.

27. Nadirov, N.K., Khafizov, R.Kh., Gareeva, Kh.Z., Sakaveva, R.F., and Dzhura, N.I. (1975).«Issledovanie tokoferolov i sterinov nekotorykh rastite'nykh masel».-Prikladnaya Biokhimiya i Mikrobilogiya 11 (5) 805-807.

28. McLaughlin, P.J. and Weihrauch, J.C. (1979)."Vitamin E content of foods".-J. Am. Diet. Assoc. 75 647-655.

29. Jung, M.Y., Yoon, S.H., and Min, D.B. (1989).«Effects of processing steps on the contents of minor compounds and oxidation of soybean oil».-J. Am. Oil Chem. Soc. 66 118-120.
30. Muller-Mulot, W. (1976)._«Rapid method for the quantitative determination of individual tocopherols in oils and fats".-J. Am. Oil Chem. Soc. 53 732-736.

31. Yamamoto, M. and Mackinney, G. (1967).- «Sterols from the fruit and seed of tomato».-Nature 213 799-800.

32. Tiscornia, E., Camurati, F., Gastaldo, P., and Pagano, M.A. (1976). — «La frazione sterolica dell'olio di pomodoro (Lycopersicon esculentum Miller)".-Riv. Ital. Sost. Grasse 53 119-129.

33. Lercker, G. (1983)._- -Short capillary columns in the analysis of lipids».-J. Chromat. 279 543-548.

34. Chow, E.T.S. and Jen, J.J. (1978).-«Phytosterol biosynthesis in ripening tomatoes".-J. Food Sci. 43 1424-1426.

35. Kiosseoglou, B. and Boskou, D. (1987).- «On the level of esterified sterols in cottonseed, tomato seed wheat germ and safflower oils".-Oleagineux 42 (4) 169-170.

36. Ismail, M., Samwel, G., and Kamel Eel-Azhari, T. (1972). - «Studies on the physical and chemical properties of tomato seed oil».-Agric. Res. Rev. $\mathbf{5 0}$ (5) 285-292.

37. Itoh, T., Tamura, T., and Matsutomo, T. (1973)."Sterol composition of 19 vegetable oils".-J. Am. Oil Chem. Soc. 50 122-125.

38. Jeong, T.M., Itoh, T., Tamura, T., and Matsutomo, T. (1974)._- Analysis of sterol fractions from twenty vegetable oils».-Lipids 9 921-927.

Recibido: Octubre 1997 Aceptado: Febrero 1998 